\title{
Michael S. Gazzaniga, Kto tu rządzi - ja czy mój mózg? Neuronauka a istnienie wolnej woli, Smak Słowa, Sopot 2013, ss. 220
}

DOI: http://dx.doi.org/10.12775/RF.2019.014

W książce Kto tu rządzi - ja czy mój mózg? Neuronauka a istnienie wolnej woli Michael S. Gazzaniga, profesor psychologii na Uniwersytecie Kalifornijskim w Santa Barbara i jeden z czołowych badaczy zajmujących się neuronauką poznawczą prowadzi rozważania nad rolą badań neurokognitywnych w debacie dotyczącej istnienia wolnej woli. Owa debata nabrała $w$ ostatnich latach rozpędu za sprawą coraz liczniejszych badań pokazujących, że świadomość podjęcia decyzji występuje już po jej podjęciu przez mózg. Na tej podstawie woliluzjoniści (willusionists), zwolennicy poglądu, że to nieświadome procesy umysłowe $\mathrm{z}$ poziomu neuronalnej maszynerii są odpowiedzialne za wszelkie nasze działania, twierdza, że wolna wola jest iluzja, a świadome doświadczenie sprowadza się do biernego odbierania tego, co nam się przydarza. Zatem na przykład świadoma implementacja intencji (zaplanowanie przyszłych działań wraz z intencją ich wykonania) według nich jest jedynie epifenomenem względem tego, do zrobienia czego zmusił nas nasz własny mózg jeszcze przed zakończeniem świadomego procesu decyzyjnego.

Gazzaniga do pewnego stopnia przyjmuje stanowisko woliluzjonistów. Broni go jednak z szerszej perspektywy, biorąc pod uwagę nie tylko temporalne zależności na poziomie milisekund pomiędzy podjęciem decyzji przez mózg a świadomością owej decyzji, ale również to, jak funkcjonalnie budowa mózgu konstytuuje nasze procesy decyzyjne i ich świadome doświadczanie, szczególnie przy uwzględnieniu wpływu społecznego.

Publikacja składa się z sześciu rozdziałów. W pierwszych trzech Gazzaniga przedstawia odkrycia z dziedziny neurokognitywistyki oraz antropologii i psychologii; pokazują one, jakie są związki między działaniem mózgu a zachowaniem oraz jak specyfika przetwarzania 
informacji przez mózg przekłada się na świadome doświadczenie (złudne według Gazzanigi) tego, że mamy wolną wolę.

Rozdział pierwszy zatytułowany Jacy jesteśmy omawia dwie kwestie. Pierwsza dotyczy podstaw budowy mózgu jako systemu połączonych ze sobą modułów, odpowiedzialnych za różne czynności funkcjonalne (takie jak rozpoznawanie twarzy, produkcja i rozumienie mowy czy integracja multisensoryczna). Gazzaniga zaczyna od omówienia historycznego rozwoju badań, w których na początku panowało przekonanie o tym, że dowolne zadanie może być realizowane przez dowolną część mózgu (zasada ekwipotencjonalności), a specyficzne uszkodzenia mózgu nie powodują ustania konkretnych funkcji, lecz proporcjonalne do wielkości uszkodzenia pogorszenie zdolności poznawczych (zasada efektu masy). Autor przechodzi od odkryć na temat wysokiej specjalizacji modułowej w mózgu (z pewnym zakresem elastyczności) do drugiej kwestii, czyli wyjątkowości człowieka na tle innych gatunków. Jak twierdzi, nie stanowi o niej (proporcjonalnie) duży mózg (który u niektórych hominidów bywał nawet większy od naszego), lecz jego organizacja funkcjonalna, w tym skomplikowana sieć połączeń aksonów, dendrytów i synaps - „ludzka kora mózgowa jest 2,75 raza większa niż kora mózgowa szympansa, choć zawiera jedynie 1,25 raza więcej neuronów [...], [co wskazuje na to, że] coraz więcej neuronów łączy się z coraz większą ilością innych neuronów" [s. 34]. Wyjątkowość człowieka przejawia się także w tym, że posiadamy ponad dwadzieścia razy więcej specjalnych komórek nerwowych, takich jak komórki von Economo, niż małpy człekokształtne. Owe komórki odpowiadają między innymi za świadomość społeczną oraz podejmowanie decyzji społecznych, co z kolei wskazuje na możliwie duży wpływ życia społecznego na rozwój mózgu i przez to przyczynienie się do rozwinięcia tak skomplikowanych wytworów, jak ludzka kultura przekładająca się z kolei na efekty kolektywnego działania $\mathrm{w}$ postaci rozwoju poznawczego, kulturowego i naukowego naszego gatunku.

Rozdział drugi pogłębia rozważania na temat modularności naszego mózgu. Jak się okazuje, specjalizacja poszczególnych obszarów mózgu ma swoją cenę. Im więcej modułów i im większy obszar one zajmuja tym trudniej o pełną oraz niezapośredniczoną komunikację między nimi. Efektem tego może być brak świadomego dostępu do przyczyn naszego zachowania.

Rozdział trzeci Gazzaniga poświęcił omówieniu odkrytego oraz badanego przez wiele lat przez siebie oraz Rogera Seperriego modułu w mózgu, nazwanego przez nich interpretatorem. Dla Gazzanigi działanie interpretatora jest najważniejszym z punktu widzenia debaty nad wolną wolą przykładem tego, jak duże mogą być koszty modularyzacji 
funkcjonalnej w mózgu. Klasyczny eksperyment pokazujący pracę interpretatora został przeprowadzony na osobach z przeciętym spoidłem wielkim (z powodu silnych napadów padaczkowych), odpowiedzialnym za komunikację pomiędzy lewą półkulą mózgu a prawą. Siedzibą interpretatora jest lewa półkula. Charakteryzuje się on sekwencyjnym przetwarzaniem informacji, a jego interpretacje mogą przyjmować postać świadomych dla nas zdań. Prawa półkula również ma swojego „interpretatora”, ale charakteryzuje się on bardziej globalnym przetwarzaniem informacji, jest głównie niemy (choć czasem może posługiwać się pojedynczymi słowami). Operacyjne odseparowanie lewopółkulowego interpretatora od prawopółkulowego powoduje, że my - czy też organizm jako całość - możemy zacząć podejmować takie decyzje, co do których nie będziemy mogli podać prawdziwych przyczyn ich podjęcia. Racje stojące za naszymi działaniami będą wtedy przyjmować formę konfabulacji. W normalnych warunkach niemy prawopółkulowy "interpretator" przekazuje przetworzone przez siebie informacje do interpretatora lewopółkulowego, który jest w stanie je zwerbalizować (do pewnego stopnia), a także poddać działania prawopółkulowego „interpretatora” dodatkowej kontroli. W przypadku operacyjnego rozdzielenia obu półkul prawa półkula zawiadująca ruchami lewej ręki może zdecydować o podjęciu takich działań, których przyczyny będą dla lewej półkuli niejasne. Jednak rolą lewopółkulowego interpretatora jest przede wszystkim podanie najbardziej prawdopodobnego wyjaśnienia działań danej osoby, a nie powstrzymywanie się od wydawania sądów w przypadku niedostatecznej porcji informacji, szczególnie od drugiej półkuli (od której nawet nie wie, że tych informacji nie otrzymuje - to kolejny koszt modularyzacji funkcjonalnej). Dlatego pacjent po operacji przecięcia spoidła wielkiego może nie zauważyć, że jest z nim coś nie tak. Odpowiednie warunki eksperymentalne pozwalają na doprowadzenie informacji tylko do jednej półkuli mózgu - np. prawa półkula widzi zabawkę i wypowiada słowo „zabawka”, jednak pacjent zapytany, dlaczego tak powiedział, nie potrafi tego wytłumaczyć przy pomocy swojego lewopółkulowego interpretatora. Może, posługując się nim, co najwyżej powiedzieć, że to pierwsze, co mu przyszło do głowy, albo że niedawno musiał myśleć o swoim siostrzeńcu, który niedługo będzie miał urodziny, i stąd przyszła mu od głowy chęć powiedzenia słowa „zabawka”. Gazzaniga przytacza bardzo wiele tego typu historii, a wszystkie według niego dowodzą iluzoryczności takich pojęć, jak , jaźń" czy „wolna wola”, ponieważ są to jedynie interpretacje decyzji podejmowanych przez różne moduły mózgu, na które nie mamy wpływu.

Wobec tego w kolejnym rozdziale Gazzaniga proponuje porzucenie idei wolnej woli i takie rozwiązanie popiera kolejnymi badania- 
mi nad „zawsze spóźnioną” świadomością względem decyzji, które wcześniej podjął już mózg. Przede wszystkim jednak popiera takie stanowisko rozważaniami na temat teorii chaosu, emergencji i systemów złożonych, z których wynika według niego, że nie tyle należy wskazywać na konkretne pojedyncze przyczyny zjawisk, ale raczej na całościowe procesy, takie jak czynniki społeczno-środowiskowe czy dynamiczna samoorganizacja. Jeżeli badamy pojedynczy mózg, to wolnej woli nie znajdziemy. Jeśli jednak weźmiemy pod uwagę system jako całość, interakcje społeczne pomiędzy różnymi mózgami i środowiskiem, to wtedy z takich interakcji wyłaniają się takie poziomy abstrakcji, jak osoby, umysły podejmujące decyzje, społeczeństwa określające i ograniczające nasze działania oraz istniejąca $\mathrm{w}$ ramach tego osobista odpowiedzialność. Tym zjawiskom autor poświęca dwa ostatnie rozdziały, pokazując, w jaki sposób możemy podejmować lepsze decyzje moralne, jak możemy lepiej stanowić i egzekwować prawo oraz dlaczego próba obrony winnego np. morderstwa z pozycji "to nie on to zrobił, lecz jego mózg" w większości przypadków nie ma większego sensu, biorąc pod uwagę emergencję, najnowsze odkrycia neurokognitywistyczne i neuronaukę społeczną. Warto w tym miejscu dodać, że Gazzaniga jest pomysłodawcą i dyrektorem projektu „Prawo a Neuronauka", realizowanego przez fundację MacArthura.

Dużą zaletą książki Gazzanigi jest przedstawienie szerokiego podejścia do tematu wolnej woli, a na poziomie funkcjonowania mózgu ujęcie tego problemu z punktu widzenia jego modułowej budowy i tego, jak działa lewopółkulowy interpretator. Powoływanie się na teorie systemów złożonych czy na powstawanie zjawisk emergentnych wydaje się trafne. Niemniej moim zdaniem Gazzaniga nie docenia wystarczająco jednostki, osoby jako (względnie) autonomicznej całości, która podejmuje świadome racjonalne decyzje, jako sprawczy (choć nie całkowicie wyizolowany) element $\mathrm{w}$ łańcuchu przyczynowym. W końcu nie wszystkie nasze decyzje mają wyraźny komponent społeczny, a jest wiele takich, których nie bylibyśmy w stanie podjacć, gdybyśmy nie byli świadomi. Choćby wtedy, gdy rozwiązujemy zadania matematyczne, uczymy się nowych rzeczy czy podejmujemy się świadomej implementacji intencji.

Kto tu rządzi - ja czy mój mózg? Neuronauka a istnienie wolnej woli będzie interesującą pozycją dla filozofów badających wolną wolę, chcących wesprzeć się w swoich rozważaniach neurokognitywistycznymi badaniami empirycznymi, które nie ograniczają się do badania aktywności mózgu na poziomie milisekund, ale biorą pod uwagę także jego ogólną modułową i funkcjonalną budowę, w tym ważną dla wrażenia posiadania jaźni i wolnej woli lewopółkulową jednostkę interpretującą. Kognitywiści odnajdą tu inspirację do kolejnych badań, 
prawnicy wstęp do neuroprawa, a czytelnicy niezajmujący się profesjonalnie tematem wolnej woli odkryja że choć prawdopodobnie na poziomie pojedynczego mózgu nie ma sensu mówić o wolnej woli, to jednocześnie znajdą pewne uzasadnienie tego, że nie jesteśmy wyłącznie biologicznymi maszynami, a zrozumienie natury w dużej mierze uniwersalnych procesów rządzących naszym poznaniem i działaniem może doprowadzić do podejmowania lepszych decyzji społecznych, być satysfakcjonującą nicią porozumienia $\mathrm{w}$ tak często podzielonym społeczeństwie.

Wojciech Sak

Uniwersytet Mikołaja Kopernika, Toruń

ORCID 0000-0002-8866-2580

e-mail:wojciech.r.sak@gmail.com 